\title{
An Insight into Weighing the Impact of Draconian Measures in the Battle Against COVID-19 [Letter]
}

This article was published in the following Dove Press journal:

Journal of Multidisciplinary Healthcare

\author{
Syeda Sakina Zehra $\mathbb{D}^{\prime}$ \\ Syeda Zoha Zehra Rizvi (iD) ${ }^{2}$ \\ 'Department of Medicine, Karachi \\ Medical and Dental College, Karachi, \\ Pakistan; ${ }^{2}$ Department of Medicine, \\ Jinnah Sindh Medical University, Karachi, \\ Pakistan
}

\section{Dear editor}

We have read the paper by Alumran ${ }^{1}$ on the benefits of precautionary measures seen in Saudi Arabia. We congratulate the author on their findings. Simultaneously, being concerned that extreme measures can be unfavorable to the public or impossible in some nations, we want to share our outlook on the study.

This study was submitted on the 12th of May when the peak had not arrived in many countries. In July, we are seeing countries coming out of the pandemic. For a worse second wave apprehended, prolonged lockdowns supported in this study would be impossible. Alternatively, early screening of cases entwined with the public being able to suspect infection by the early phase symptoms of the infection, as extracted from the UK's COVID-19 Symptom Study App or other records, and then working on the test, trace and isolate system could thwart the dreaded second wave.

The reproductive number $\left(\mathrm{R}_{\mathrm{o}}\right)$ used in this study had been derived by observing the documented cases. Asymptomatic cases could also be contagious and hence affect the $\mathrm{R}_{\mathrm{o}}$. Inculcating the new-found $\mathrm{R}_{\mathrm{o}}$, issued by wide-scale testing, that also includes the contagiousness of asymptomatic cases can give a clearer picture.

Besides comorbidities and age composition, the imported strain of the virus, HLA types of a population, and other community-level confounders like the local epidemic record, which can inform about the drug intake of a population, can affect the case fatality rate across different populations.

This study provides evidence that due to lockdown and screening for asymptomatic cases both positive cases and mortality can be diluted against the expected. Conversely, unintended reactions to intense precautionary measures like prevalent desperation among families due to visiting restrictions thrust by hospitals ${ }^{2}$ and possible Post-traumatic Stress Disorder in the post-COVID-19 era are also real. Turning the focus toward least restrictive measures.

Questions have arisen on the usefulness of quarantine for highly transmissible diseases due to its accompanying laws and limitations. ${ }^{3}$ Moreover, countries like South Korea, Hong Kong, Singapore, Taiwan, and Japan did not execute draconian measures of lockdowns but rather buildup their test, trace and isolate system initially in the pandemic and successfully controlled the virus.

The author highlighted the importance of public awareness. We will have to make sure that public awareness is being done on different grounds. Elective surgery patients are delaying their surgery mainly due to the overwhelming draconian pre-op quarantine
Correspondence: Syeda Zoha Zehra Rizvi B-349, Block 6, Gulshan-e-lqbal, Karachi, Pakistan

Tel +923342721995

Email syedazohazehra@gmail.com
Journal of Multidisciplinary Healthcare 2020:13 839-840

DovePress in $\square$ 
measures ${ }^{4}$ but this can also be due to ignorance regarding the dangers of not having surgery.

COVID-19 is affecting trade, travel, and economy of the world. The economic losses can be decreased by effectuating spatial lockdowns in certain areas with higher activities to risk the spread, than uniformly enforcing them throughout a city or a country. ${ }^{5}$

In conclusion, we agree that draconian measures have benefitted nations against COVID-19, but on the other side of the coin, it has come at a price. Nevertheless, more creative and comprehensive measures that are also least restrictive should be in action for the anticipated second wave.

\section{Disclosure}

The authors report no conflicts of interest in this communication.

\section{References}

1. Alumran A. Role of precautionary measures in containing the natural course of novel coronavirus disease. J Multidiscip Healthc. 2020;13:615-620. doi:10.2147/JMDH.S261643

2. Tom Alsaigh M. Let's stop the Draconian visiting restrictions medscape; 2020. Available from: https://www.medscape.com/viewarticle/ 931131. Accessed May 27, 2020.

3. Parmet WE, Sinha MS. Covid-19 - the law and limits of quarantine. N Engl J Med. 2020;382(15):e28. doi:10.1056/NEJMp2004211

4. Bird S. Coronavirus: pre-op rules are keeping people from vital surgery, warns senior doctor. Telegraph. 2020;2020.

5. Fajgelbaum P, Khandelwal A, Kim W, Mantovani C, Schaal E. Optimal Lockdown in a Commuting Network. National Bureau of Economic Research; 2020:0898-2937.

Dove Medical Press encourages responsible, free and frank academic debate. The content of the Journal of Multidisciplinary Healthcare 'letters to the editor' section does not necessarily represent the views of Dove Medical Press, its officers, agents, employees, related entities or the Journal of Multidisciplinary Healthcare editors. While all reasonable steps have been taken to confirm the content of each letter, Dove Medical Press accepts no liability in respect of the content of any letter, nor is it responsible for the content and accuracy of any letter to the editor.

\section{Publish your work in this journal}

The Journal of Multidisciplinary Healthcare is an international, peerreviewed open-access journal that aims to represent and publish research in healthcare areas delivered by practitioners of different disciplines. This includes studies and reviews conducted by multidisciplinary teams as well as research which evaluates the results or conduct of such teams or healthcare processes in general. The journal covers a very wide range of areas and welcomes submissions from practitioners at all levels, from all over the world. The manuscript management system is completely online and includes a very quick and fair peer-review system. Visit http://www.dovepress.com/testimonials. php to read real quotes from published authors. 